\title{
HIV-Related Stigma and Discrimination (S\&D) among Healthcare Workers (HCW) in Government Healthcare Facilities in Malaysia: Is It Real?
}

\author{
Zailatul Hani Mohamad Yadzir ${ }^{1}$, Mazliza Ramly ${ }^{1} \&$ Anita Suleiman ${ }^{1}$ \\ ${ }^{1}$ HIV/STI/Hep C Sector, Disease Control Division, Ministry of Health Malaysia, Federal Government \\ Administrative Centre, Putrajaya, Malaysia \\ Correspondence: Zailatul Hani Mohamad Yadzir, HIV/STI/Hep C Sector, Disease Control Division, Ministry of \\ Health Malaysia, Level 4, Block E10, Complex E, Federal Government Administrative Centre, 62590 Putrajaya, \\ Malaysia.
}

Received: June 3, 2021 Accepted: September 8, 2021 Online Published: October 8, 2021

doi:10.5539/gjhs.v13n11p66 URL: https://doi.org/10.5539/gjhs.v13n11p66

\begin{abstract}
Stigma and discrimination (S\&D) undermine quality of life of people living with HIV (PLHIV) and their access to health services. In this context, an understanding of current stigmatizing attitudes among HCW towards PLHIV from the perspective of Malaysia healthcare setting is crucial to plan for service delivery improvement that is non-stigmatizing and non-discriminatory. The objective of this study was to examine and measure the level of S\&D towards PLHIV among HCW in selected government facilities.

A cross-sectional study was undertaken from July to August 2020 in five government hospitals and six government health clinics in Malaysia. Two sets of a validated self-administered questionnaires, one for HCW and another one for PLHIV were used to assess HIV-related S\&D. This survey was conducted via web-based platform.

Overall, $3880 \mathrm{HCW}$ and 1173 PLHIV participated in this study. This study found significant proportion of HCW were having stigmatizing attitudes towards PLHIV. This includes fear of taking blood from PLHIV (87\%) and double gloving when attending PLHIV (64\%) probably due to fear of contracting HIV. In addition, $45 \%$ of $\mathrm{HCW}$ agreed that women living with HIV (WLHIV) should be prohibited from having children. Although HCW have fears for contracting HIV, their consciences and integrity allowed them to display some positive attitudes towards PLHIV with the majority of HCW $84 \%$ and $79 \%$ stated that they having observed others in their facility expressed willingness to care and providing good care to PLHIV. On PLHIV experience, only $12 \%$ of them reported that they had ever experienced stigma when accessing health services.

The findings of this study shared a worrying magnitude of stigma towards PLHIV among HCW in Malaysia. Nevertheless, ethics and professionalism are upheld through giving good care and services to PLHIV. However, stigma reduction intervention programmes are still needed for HCW to ensure continuous excellent service delivery.
\end{abstract}

Keywords: Human immunodeficiency virus/acquired immunodeficiency syndrome (HIV/AIDS), stigma and discrimination (S\&D), healthcare workers (HCW), people living with HIV (PLHIV), women living with HIV (WLHIV)

\section{Introduction}

Despite global progress in the treatment and care of human immunodeficiency virus (HIV), PLHIV still continue to report experiencing HIV-related S\&D within the healthcare setting (Vorasane et al., 2017). The S\&D that a PLHIV experienced at a healthcare setting resulted in lower access to HIV treatment, low utilization of HIV care services, poorer antiretroviral therapy (ART) adherence and thus poorer treatment outcomes (Pitasi et al., 2018; Tran et al., 2019).

Reducing HIV-related S\&D in healthcare setting is paramount because they are the first line of care, treatment and support services that PLHIV can access to help them manage their response to HIV (Houstan et al., 2019). Aside from access to services, other critical reasons for reducing HIV-related S\&D is the negative effect on self-esteem and mental health (Vorasane et al., 2017). Anxiety, depression, suicidal ideation, emotional health, psychological 
well-being, life satisfaction and quality of life have all been reported to be negatively impacted by S\&D (Vorasane et al., 2017; Houstan et al., 2019).

Research has shown that HIV-related S\&D in healthcare setting may occur in many different forms, including: denial of care to a PLHIV (Ogden \& Nyblade, 2005), verbal abuse to a PLHIV (Mukasa, 2006; Nyblade, Stangl, Weiss \& Ashburn, 2009), lower standards of care to a PLHIV (Maluwa, Aggleton \& Parker, 2002; Chambers et al., 2015), placement of a PLHIV at the end of a queue (Ogden \& Nyblade, 2005), disclosure of a patient's HIV status to colleagues/family members without consent, irrespective of when PLHIV arrived at the facility and gossiping about the patient (Mukasa, 2006).

In this context, an understanding of current stigmatizing attitudes among HCW towards PLHIV from the perspective of Malaysia healthcare setting is crucial to plan for service delivery improvement that is non-stigmatizing and non-discriminatory. The objective of this study was to examine and measure the level of S\&D towards PLHIV among HCW in selected government facilities.

\section{Methods}

\subsection{Study Setting and Sample Size}

This study was a cross-sectional study using a validated self-administered questionnaire survey which was conducted from July to August 2020 via online. Five government hospitals and six government health clinics were selected from six states; Penang, Selangor, Kuala Lumpur, Johor, Melaka and Pahang. The six states were selected as $70 \%$ of the 2019 reported new HIV cases were contributed from these states (Malaysia Global AIDS Monitoring, 2020). All the eleven selected study sites provided HIV/AIDS care services to the public.

There were two target subjects for this study which were HCW and PLHIV. The inclusion criteria for HCW included: worked for at least six months in the selected study sites, directly involved in care of PLHIV and agreed to participate in the study voluntarily. PLHIV were enrolled according to the predetermined inclusion criteria: age 18 years and above, registered as patient in the selected study sites, living with HIV, able to understand Malay or English language and willing to provide informed consent. No personal information was asked to maintain anonymity.

For the recruitment of potential $\mathrm{HCW}$, a recruitment message with a hyperlink or QR code to the online survey website was disseminated via email or smart phone messenger apps (e.g., Whatsapp, Telegram), while PLHIV were approached by clinic staff or case worker during their scheduled appointments.

Sample size was calculated to be 3675 consisting of 1904 HCW and 1771 PLHIV assuming 95\% confidence level with 5\% margin error and 50\% response rate.

\subsection{Survey Tool}

The instrument used in this study is a self-administered online questionnaire survey via web-based platform. Two sets of a questionnaires, one for HCW and another one for PLHIV were used to assess HIV-related S\&D. The questionnaire for HCW was adapted from a globally standardised tool for measurement of HIV-related stigma among health facility staff (Nyblade et al., 2013) and the questionnaire for PLHIV experience was adapted from similar study in Thailand (Srithanaviboonchai et al., 2017).

The HCW questionnaire consisted of two main parts. The first part consisted of socio-demographic section which intended to discover the demographic namely gender, HIV/AIDS training and experience of working with PLHIV. The second part consisted of five sections; infection control, health facility environment, health facility policies, opinions about PLHIV and antenatal care, prevention of mother-to-child transmission and delivery wards. While the questionnaire for PLHIV included information on patient experience at the healthcare facility.

\subsection{Ethical Considerations}

The study received ethical approval from the Medical Research and Ethics Committee, Ministry of Health Malaysia and this study was registered under Malaysia National Medical Research Registry (NMRR) with the identification number NMRR-20-1932-55728.

\subsection{Statistical Analysis}

Statistical analysis was done using the Statistical Package for Social Sciences (SPSS 26.0) software. Data was entered, cleaned and checked before data analysis. Frequencies and simple associations were calculated. $P$-value less than 0.05 was taken as the significance level for all analyses. 


\section{Results}

\subsection{Demographic Characteristics}

In total, $3880 \mathrm{HCW}$ and 1173 PLHIV participated in this study. HCW were predominantly female $3300(85 \%)$ with 1: 5.96 male and female sex ratio. Of the $3880 \mathrm{HCW}, 3086(80 \%)$ worked in hospitals and $794(20 \%)$ in health clinics. While for PLHIV, 767 (65\%) receiving care in hospitals and $406(35 \%)$ in health clinics. More than two-thirds of the HCW 2581 (67\%) had attended training on HIV/AIDS and 2037 (53\%) HCW claimed having experience in working at hospital/clinic/department that specialized in HIV care and treatment.

\subsection{Infection Control Concerns in Regards with a PLHIV in Health Facility}

The findings in this section are shown in Table 1. Eighty seven percent (87\%) and $84 \%$ of the HCW responded fear of taking blood and dressing the wounds of a PLHIV, respectively. However, the differences were not statistically significant. More than half $(64 \%)$ of HCW stated that they wore double gloves when attending PLHIV with a significant difference. Sixty three percent $(63 \%)$ of $\mathrm{HCW}$ also indicated that they always wear gloves during all aspects of the care and services for a PLHIV with a significant difference. Seventy three percent (73\%) of HCW responded using additional specific infection measures when attending PLHIV, however, the difference was not statistically significant.

Table 1. Infection control concerns in regards with a PLHIV in health facility

\begin{tabular}{|c|c|c|c|c|c|c|c|}
\hline \multirow{2}{*}{ Item } & & & \multicolumn{2}{|c|}{ Worried } & \multicolumn{2}{|c|}{ Not Worried } & \multirow{2}{*}{$P$-value } \\
\hline & & & $\mathrm{n}$ & $\%$ & $\mathrm{n}$ & $\%$ & \\
\hline 1 & $\begin{array}{l}\text { How worried would you be if you touched the clothing of a } \\
\text { PLHIV? }\end{array}$ & $(\mathrm{N}=3618) *$ & 1949 & 54 & 1669 & 46 & 0.000 \\
\hline 2 & $\begin{array}{l}\text { How worried would you be if you dressed the wounds of a } \\
\text { PLHIV? }\end{array}$ & $(\mathrm{N}=3407) *$ & 2846 & 84 & 561 & 16 & 0.663 \\
\hline 3 & How worried would you be if you taking blood from a PLHIV? & $(\mathrm{N}=3302) *$ & 2867 & 87 & 435 & 13 & 0.578 \\
\hline 4 & $\begin{array}{l}\text { How worried would you be if you took the temperature of a } \\
\text { PLHIV? }\end{array}$ & $(\mathrm{N}=3451) *$ & 1161 & 34 & 2290 & 66 & 0.006 \\
\hline \multirow{2}{*}{\multicolumn{2}{|c|}{ Item }} & & \multicolumn{2}{|l|}{ Yes } & \multicolumn{2}{|l|}{ No } & \multirow{2}{*}{$P$-value } \\
\hline & & & $\mathrm{n}$ & $\%$ & $\mathrm{n}$ & $\%$ & \\
\hline 5 & $\begin{array}{l}\text { Do you avoid physical contact when providing care or services } \\
\text { to PLHIV? }\end{array}$ & $(\mathrm{N}=3488) *$ & 1077 & 31 & 2411 & 69 & 0.010 \\
\hline 6 & $\begin{array}{l}\text { Do you wear double gloves when providing care or services to } \\
\text { PLHIV? }\end{array}$ & $(\mathrm{N}=3476) *$ & 2226 & 64 & 1250 & 36 & 0.011 \\
\hline 7 & $\begin{array}{l}\text { Do you always wear gloves during all aspects of the care and } \\
\text { services when providing care or services to PLHIV? }\end{array}$ & $(\mathrm{N}=3507) *$ & 2207 & 63 & 1300 & 37 & 0.003 \\
\hline 8 & $\begin{array}{l}\text { Do you use any specific infection measures for PLHIV which } \\
\text { you do not use for other patients? }\end{array}$ & $(\mathrm{N}=3426) *$ & 2508 & 73 & 918 & 27 & 0.081 \\
\hline
\end{tabular}

* Total number of HCW minus who answered Not Applicable

\subsection{Health Facility Environment in Regards with a PLHIV}

The findings from this section are shown in Table 2. Majority of HCW $84 \%$ and $79 \%$ reported having observed others in their facility expressed willingness to care and providing good care to PLHIV with a significant differences. HCW were also unconcerned about stigmatization from family members and friends for providing care to PLHIV (all the P values $<0.05$ ). Sixty five percent $(65 \%)$ of the HCW were also comfortable to work with colleagues living with HIV. 
Table 2. Health facility environment in regards to a PLHIV

\begin{tabular}{|c|c|c|c|c|c|c|c|}
\hline \multirow{2}{*}{ Item } & & & \multicolumn{2}{|l|}{ Yes } & \multicolumn{2}{|l|}{ No } & \multirow{2}{*}{$P$-value } \\
\hline & & & $\mathrm{n}$ & $\%$ & $\mathrm{n}$ & $\%$ & \\
\hline 1 & $\begin{array}{l}\text { In the last } 12 \text { months, have you provided service to PLHIV in your } \\
\text { health facility? }\end{array}$ & $(\mathrm{N}=3880)$ & 2388 & 62 & 1492 & 38 & 0.000 \\
\hline 2 & $\begin{array}{l}\text { In the last } 12 \text { months, have you observed healthcare provider } \\
\text { unwilling to care for a patient living with or thought to be living } \\
\text { with HIV at your health facility? }\end{array}$ & $(\mathrm{N}=2388) *$ & 382 & 16 & 2006 & 84 & 0.005 \\
\hline 3 & $\begin{array}{l}\text { In the last } 12 \text { months, have you observed healthcare providers who } \\
\text { provide poorer quality of care to a people living with or suspected } \\
\text { to be living with HIV, compared to other patients at your health } \\
\text { facility? }\end{array}$ & $(\mathrm{N}=2388) *$ & 505 & 21 & 1883 & 79 & 0.000 \\
\hline 4 & $\begin{array}{l}\text { In the last } 12 \text { months, have you observed healthcare providers } \\
\text { talking badly about people living with or suspected to be living } \\
\text { with HIV at your health facility? }\end{array}$ & $(\mathrm{N}=2388) *$ & 682 & 29 & 1706 & 71 & 0.014 \\
\hline \multirow{2}{*}{\multicolumn{2}{|c|}{ Item }} & & \multicolumn{2}{|c|}{ Worried } & \multicolumn{2}{|c|}{ Not Worried } & \\
\hline & & & $\mathrm{n}$ & $\%$ & $\mathrm{n}$ & $\%$ & \\
\hline 5 & $\begin{array}{l}\text { How worried are you of people talking badly about you because } \\
\text { you provide care for PLHIV? }\end{array}$ & $(\mathrm{N}=3880)$ & 1128 & 29 & 2752 & 71 & 0.000 \\
\hline 6 & $\begin{array}{l}\text { How worried are you of friends and family avoiding you because } \\
\text { you provide care for PLHIV? }\end{array}$ & $(\mathrm{N}=3880)$ & 1333 & 34 & 2547 & 66 & 0.003 \\
\hline 7 & $\begin{array}{l}\text { How worried are you of colleagues avoiding you because you } \\
\text { provide care for PLHIV? }\end{array}$ & $(\mathrm{N}=3880)$ & 1028 & 26 & 2852 & 74 & 0.000 \\
\hline 8 & $\begin{array}{l}\text { In your opinion, how reluctant are healthcare provider in your } \\
\text { facility, to work with colleagues living with HIV, regardless of } \\
\text { their profession? }\end{array}$ & $(\mathrm{N}=3880)$ & 1343 & 35 & 2537 & 65 & 0.989 \\
\hline
\end{tabular}

* Total number of HCW who answered Yes in Item 1

\subsection{Health Facility Policies in Regards with a PLHIV}

The findings in this section are shown in Table 3. Eighty two percent (82\%) of the HCW disagreed with testing patients for HIV infection without consent with a statistically significant. Majority of HCW (97\%) agreed that their facility has standardised procedures/protocols on HIV that reduce risk of infection. More than two-thirds (68\%) of $\mathrm{HCW}$ also agreed that their facility has written guidelines to protect PLHIV from discrimination. However, the differences were not statistically significant.

Table 3. Health facility policies in regards to a PLHIV

\begin{tabular}{|c|c|c|c|c|c|c|c|}
\hline \multirow{2}{*}{ Item } & & & \multicolumn{2}{|c|}{ Agree } & \multicolumn{2}{|c|}{ Disagree } & \multirow{2}{*}{$P$-value } \\
\hline & & & $\mathrm{n}$ & $\%$ & $\mathrm{n}$ & $\%$ & \\
\hline 1 & $\begin{array}{l}\text { In my facility, it is not acceptable to test a patient for HIV } \\
\text { without their knowledge }\end{array}$ & $(\mathrm{N}=3880)$ & 3177 & 82 & 703 & 18 & 0.031 \\
\hline \multirow{2}{*}{\multicolumn{2}{|c|}{ Item }} & & Yes & & No & & \multirow{2}{*}{$P$-value } \\
\hline & & & $\mathrm{n}$ & $\%$ & $\mathrm{n}$ & $\%$ & \\
\hline 2 & $\begin{array}{l}\text { I will get into trouble at work if I discriminate against } \\
\text { PLHIV }\end{array}$ & $(\mathrm{N}=3880)$ & 2036 & 52 & 1844 & 48 & 0.597 \\
\hline
\end{tabular}




\begin{tabular}{|c|c|c|c|c|c|c|c|}
\hline \multirow{2}{*}{ Item } & & & \multicolumn{2}{|l|}{ Agree } & \multicolumn{2}{|c|}{ Disagree } & \multirow{2}{*}{$P$-value } \\
\hline & & & $\mathrm{n}$ & $\%$ & $\mathrm{n}$ & $\%$ & \\
\hline 3 & $\begin{array}{l}\text { There are standardised procedures/protocols in my health } \\
\text { facility that reduce my risk of becoming infected with HIV }\end{array}$ & $(\mathrm{N}=3880)$ & 3774 & 97 & 106 & 3 & 0.252 \\
\hline \multirow{2}{*}{ Item } & & & Yes & & No & & \multirow{2}{*}{$P$-value } \\
\hline & & & $\mathrm{n}$ & $\%$ & $\mathrm{n}$ & $\%$ & \\
\hline 4 & $\begin{array}{l}\text { My health facility has written guidelines to protect PLHIV } \\
\text { from discrimination }\end{array}$ & $(\mathrm{N}=3880)$ & 2637 & 68 & 1243 & 32 & 0.631 \\
\hline
\end{tabular}

\subsection{Opinions about PLHIV}

The findings from this section are shown in Table 4. Slightly more than half (53\%) of the HCW agreed that those infected with HIV because they engaged in irresponsible behaviours with a significant difference. As for reproductive right, $55 \%$ of HCW agreed that WLHIV should be allowed to get pregnant.

Table 4. Opinions about PLHIV

\begin{tabular}{|c|c|c|c|c|c|c|c|}
\hline \multirow{2}{*}{\multicolumn{3}{|c|}{ Item }} & \multicolumn{2}{|c|}{ Agree } & \multicolumn{2}{|c|}{ Disagree } & \multirow{3}{*}{$\frac{P \text {-value }}{0.642}$} \\
\hline & & & & \multirow{2}{*}{$\frac{\%}{23}$} & \multirow{2}{*}{$\begin{array}{ll}\mathrm{n} \\
2996\end{array}$} & \multirow{2}{*}{$\begin{array}{l}\% \\
77\end{array}$} & \\
\hline 1 & Most PLHIV do not care if they infect other people & $(\mathrm{N}=3880)$ & & & & & \\
\hline 2 & PLHIV should feel ashamed of themselves & $(\mathrm{N}=3880)$ & 613 & 16 & 3267 & 84 & 0.357 \\
\hline 3 & Most PLHIV have had many sexual partners & $(\mathrm{N}=3880)$ & 1449 & 37 & 2431 & 63 & 0.775 \\
\hline 4 & $\begin{array}{l}\text { People get infected with HIV because they engage in } \\
\text { irresponsible behaviours }\end{array}$ & $(\mathrm{N}=3880)$ & 2039 & 53 & 1841 & 47 & 0.033 \\
\hline 5 & HIV is punishment for bad behaviours & $(\mathrm{N}=3880)$ & 751 & 19 & 3129 & 81 & 0.002 \\
\hline 6 & $\begin{array}{l}\text { Women living with HIV should be allowed to get } \\
\text { pregnant if they wish }\end{array}$ & $(\mathrm{N}=3880)$ & 2119 & 55 & 1761 & 45 & 0.003 \\
\hline 7 & $\begin{array}{l}\text { If I had choice, I would prefer not to provide services } \\
\text { to people who inject illegal drugs }\end{array}$ & $(\mathrm{N}=3880)$ & 1569 & 40 & 2311 & 60 & 0.042 \\
\hline 8 & $\begin{array}{l}\text { If I had choice, I would prefer not to provide services } \\
\text { to men who have sex with men }\end{array}$ & $(\mathrm{N}=3880)$ & 1264 & 33 & 2616 & 67 & 0.009 \\
\hline 9 & $\begin{array}{l}\text { If I had choice, I would prefer not to provide services } \\
\text { to female sex workers }\end{array}$ & $(\mathrm{N}=3880)$ & 979 & 25 & 2901 & 75 & 0.830 \\
\hline
\end{tabular}

\subsection{Antenatal Care, Prevention of Mother-to-Child Transmission and Delivery Wards}

The findings in this section are shown in Table 5. Majority of HCW (81\%) stated that they were worried when assisting during labor and delivery of WLHIV, however, the difference was not statistically significant. Seventy percent $(70 \%)$ of HCW agreed that family of pregnant WLHIV has a right to know her HIV status with a significant difference. More than half $(62 \%)$ of HCW agreed that WLHIV should not get pregnant if they already have children. 
Table 5. Antenatal care, prevention of mother-to-child transmission and delivery wards

\begin{tabular}{|c|c|c|c|c|c|c|c|}
\hline & \multirow{2}{*}{ Item } & & \multicolumn{2}{|c|}{ Yes } & \multicolumn{2}{|c|}{ No } & \multirow{2}{*}{$P$-value } \\
\hline & & & $\mathrm{n}$ & $\%$ & $\mathrm{n}$ & $\%$ & \\
\hline \multirow[t]{3}{*}{1} & $\begin{array}{l}\text { Are you involved with pregnant women during antenatal } \\
\text { care, prevention of HIV transmission from mother-to-child, } \\
\text { in the wards or labor rooms? }\end{array}$ & $(\mathrm{N}=3880)$ & 1396 & 36 & 2484 & 64 & 0 \\
\hline & \multirow{2}{*}{ Item } & & \multicolumn{2}{|c|}{ Worried } & \multicolumn{2}{|c|}{ Not Worried } & $D_{\text {O }}$ \\
\hline & & & $\mathrm{n}$ & $\%$ & $\mathrm{n}$ & $\%$ & $T$-value \\
\hline \multirow[t]{3}{*}{2} & $\begin{array}{l}\text { How worried are you about assisting in labor and delivery if } \\
\text { the woman living with HIV? }\end{array}$ & $(\mathrm{N}=1334) *$ & 1087 & 81 & 247 & 19 & 0.639 \\
\hline & \multirow{2}{*}{ Item } & & \multicolumn{2}{|c|}{ Yes } & \multicolumn{2}{|c|}{ No } & \multirow{2}{*}{$P$-value } \\
\hline & & & $\mathrm{n}$ & $\%$ & $\mathrm{n}$ & $\%$ & \\
\hline 3 & $\begin{array}{l}\text { In the last } 12 \text { months, have you observed other healthcare } \\
\text { providers performing an HIV test on a pregnant woman } \\
\text { without her informed consent? }\end{array}$ & $(\mathrm{N}=1396) \ddagger$ & 265 & 19 & 1131 & 81 & 0.002 \\
\hline 4 & $\begin{array}{l}\text { In the last } 12 \text { months, have you observed other healthcare } \\
\text { providers neglecting a woman living with HIV during labor } \\
\text { and delivery because of her HIV status? }\end{array}$ & $(\mathrm{N}=1396) \ddagger$ & 90 & 6 & 1306 & 94 & 0.110 \\
\hline 5 & $\begin{array}{l}\text { In the last } 12 \text { months, have you observed other healthcare } \\
\text { providers using additional infection-control procedures } \\
\text { (e.g., double gloves) with a woman living with HIV during } \\
\text { labor and delivery because of her HIV status? }\end{array}$ & $(\mathrm{N}=1396) \ddagger$ & 962 & 69 & 434 & 31 & 0.000 \\
\hline 6 & $\begin{array}{l}\text { In the last } 12 \text { months, have you observed other healthcare } \\
\text { providers disclosing the status of a pregnant woman living } \\
\text { with HIV to others without her consent? }\end{array}$ & $(\mathrm{N}=1396) \ddagger$ & 166 & 12 & 1230 & 88 & 0.142 \\
\hline \multirow[t]{3}{*}{7} & $\begin{array}{l}\text { In the last } 12 \text { months, have you observed other healthcare } \\
\text { providers impose compulsory use of family planning } \\
\text { methods as a requirement to enable a woman living with } \\
\text { HIV to receive HIV treatment? }\end{array}$ & $(\mathrm{N}=1396) \ddagger$ & 819 & 59 & 577 & 41 & 0.174 \\
\hline & \multirow{2}{*}{ Item } & & \multicolumn{2}{|c|}{ Agree } & \multicolumn{2}{|c|}{ Disagree } & \multirow{2}{*}{$P$-value } \\
\hline & & & $\mathrm{n}$ & $\%$ & $\mathrm{n}$ & $\%$ & \\
\hline 8 & $\begin{array}{l}\text { If a pregnant woman is HIV positive, her family has a right } \\
\text { to know }\end{array}$ & $(\mathrm{N}=3880)$ & 2735 & 70 & 1145 & 30 & 0.000 \\
\hline 9 & Pregnant women who refuse HIV testing are irresponsible & $(\mathrm{N}=3880)$ & 3549 & 91 & 331 & 9 & 0.070 \\
\hline 10 & $\begin{array}{l}\text { Women living with HIV should not get pregnant if they } \\
\text { already have children }\end{array}$ & $(\mathrm{N}=3880)$ & 2406 & 62 & 1474 & 38 & 0.479 \\
\hline 11 & $\begin{array}{l}\text { It can be appropriate to sterilize a woman living with HIV, } \\
\text { even if this is not her choice }\end{array}$ & $(\mathrm{N}=3880)$ & 1141 & 29 & 2739 & 71 & 0.512 \\
\hline
\end{tabular}

\footnotetext{
* Total number of HCW minus who answered Not Applicable;
}

¥ Total number of $\mathrm{HCW}$ who answered Yes in Item 1.

\subsection{PLHIV Experience}

On PLHIV experience, only $12 \%$ of them reported that they had ever experienced stigma when accessing health services, however, the difference was not statistically significant (Table 6). 
Table 6. PLHIV experience

\begin{tabular}{|c|c|c|c|c|c|c|c|}
\hline \multirow{2}{*}{ Item } & & & \multicolumn{2}{|l|}{ Yes } & \multicolumn{2}{|l|}{ No } & \multirow{2}{*}{$P$-value } \\
\hline & & & $\mathrm{n}$ & $\%$ & $\mathrm{n}$ & $\%$ & \\
\hline 1 & Was information about your health explained clearly? & $(\mathrm{N}=1173)$ & 1158 & 99 & 15 & 1 & 0.231 \\
\hline 2 & Was the clinic welcoming and friendly? & $(\mathrm{N}=1173)$ & 1152 & 98 & 21 & 2 & 0.735 \\
\hline 3 & $\begin{array}{l}\text { Were you treated with respect during your visit to this } \\
\text { particular health facility? }\end{array}$ & $(\mathrm{N}=1173)$ & 1156 & 99 & 17 & 1 & 0.277 \\
\hline 4 & $\begin{array}{l}\text { Were privacy and confidentiality protected during your visit to } \\
\text { this particular health facility? }\end{array}$ & $(\mathrm{N}=1173)$ & 1113 & 95 & 60 & 5 & 0.294 \\
\hline 5 & $\begin{array}{l}\text { Did you experience discrimination from a healthcare provider } \\
\text { or other staff member? }\end{array}$ & $(\mathrm{N}=1173)$ & 141 & 12 & 1032 & 88 & 0.734 \\
\hline 6 & $\begin{array}{l}\text { Were you involved with decision-making about your care and } \\
\text { treatment? }\end{array}$ & $(\mathrm{N}=1173)$ & 1056 & 90 & 117 & 10 & 0.758 \\
\hline $7 \mathrm{a}$ & Did your doctor spend enough time with you during your visit? & $(\mathrm{N}=1165) *$ & 1132 & 97 & 33 & 3 & 0.042 \\
\hline $7 b$ & $\begin{array}{l}\text { Did your paramedic (nurse/medical assistant) spend enough } \\
\text { time with you during your visit? }\end{array}$ & $(\mathrm{N}=1134) *$ & 1109 & 98 & 25 & 2 & 0.001 \\
\hline
\end{tabular}

* Total number of PLHIV minus who answered Not Applicable.

\section{Discussion}

The current study noted a relatively high prevalence of HIV-related stigma among HCW in the country. In this study, $34-87 \%$ of $\mathrm{HCW}$ were worried about performing various day-to-day duties i.e., touching clothing, dressing wounds, drawing blood and taking temperature for PLHIV. This study also revealed that majority of HCW (81\%) involved in the wards or labor rooms were worried when assisting during labor and delivery of WLHIV. Findings in this study are slightly higher compare to other research; in Thailand, 32-66\% of $738 \mathrm{HCW}$ were worried about similar duties, while $23-67 \%$ of more than $1000 \mathrm{HCW}$ from multiple countries were similarly concerned (Nyblade et al., 2013; International Health Policy Program Thailand, 2014).

In term of HIV-related practices, $63-73 \%$ of $\mathrm{HCW}$ indicated that they wore double gloves, wearing gloves during all aspects of the care and services and using additional specific infection measures when attending PLHIV. However, these practices are not in line with the national Policies and Procedures on Infection Prevention and Control, in which double gloving is only recommended during some Exposure Prone Procedures (EPPs) e.g., orthopaedic and gynaecological operations or when attending major trauma incidents (Policies and Procedures on Infection Prevention and Control, 2019). Similar to the findings of this study, a study in Ghana found $65.7 \%$ of nurses put on gowns and gloves with any contact with PLHIV emanating from fear of contracting HIV during clinical practice (Boakye \& Mavhandu-Mudzusi, 2019). This finding highlights a lack of understanding regarding the primary principle underlying Standard/Universal Precautions i.e., the precaution applies universally and not selectively. The value of Standard/Universal Precautions is that they protect HCW and patients against infection with a range of pathogens, not just HIV (Yasin, Fisseha, Mekonnen, \& Yirdaw, 2019).

Stigma often leads to the discriminatory attitudes and avoidance of duties. However, in this study, majority of HCW reported having observed others in their facility being willing to care and providing good care to PLHIV. Majority of HCW (94\%) also stated that they never observed others in their facility neglecting WLHIV during labor and delivery. Moreover, $\mathrm{HCW}$ were also unconcerned about stigmatization from family members and friends for providing care to PLHIV. At the same time, $65 \%$ of the HCW in this study were comfortable to work with colleagues living with HIV. These findings were also confirmed through the PLHIV experience where only a small percentage of them had ever experienced stigma when seeking health care (12\%). Many of them also indicated that the clinic was welcoming and friendly and they were treated with respect when accessing health services. This was quite encouraging and commendable, considering HCW demonstration of fear of infection through day-to-day duties. The findings of this study are in corroborated with studies conducted by Boakye \& Mavhandu-Mudzusi (2019) and Ledda et al. (2017), that although HCW have fears for contracting HIV, their consciences and integrity allowed them to overcome their fear and display some positive attitudes when attending to PLHIV.

It was good to observe that the majority of HCW in this study disagreed that HIV test can be done without the 
knowledge or permission of the patients. This belief is in keeping with the current practice in Malaysia, which follows the guidelines issued by the World Health Organization (WHO) in 2007 where explicit consent must be obtained from the patient before HIV testing can be done. In critically ill or unconscious patients who may not be able to provide informed consent to HIV testing and counselling, consent should be obtained from the patient's next-of-kin, guardian or other care given. Only in the absence of such a person, healthcare providers should act according to the best interests of the patient concerned (WHO, 2007).

Similar to other studies conducted by Lui, Sarangapany, Begley, Coote \& Kishore (2014) and Ledda et al. (2017), this study found that a fraction of HCW had negative or prejudicial attitudes towards PLHIV. Slightly more than half of the HCW (53\%) opined that people get infected with HIV because they engage in irresponsible behaviours. Despite, ethics and professionalism are upheld through their services. More than half of the HCW have no issues on providing services to key populations i.e., people who inject illegal drugs, men who have sex with men and female sex workers.

This study revealed that $45 \%$ of the HCW did not agree with the idea of WLHIV having the right to procreate and $62 \%$ of the HCW also agreed that WLHIV should not get pregnant if they already have children. Similar findings were reported in a multinational study of over $1000 \mathrm{HCW}, 40 \%$ were against WLHIV having the right to procreate (Srithanaviboonchai et al., 2017). This is unfortunate, considering that the availability of effective ART to suppress viral load which allows WLHIV to get pregnant without risk of HIV being passed on to their baby. In addition, the rights to have children is the women to choose, regardless of HIV status.

In this study, $70 \%$ of HCW opined that family of pregnant WLHIV has a right to know her HIV status. Nevertheless, $88 \%$ of HCW reported that they never observed others in their facility disclosing the status of a WLHIV to others without her consent. These findings were also compatible with the PLHIV experience where 95\% of them stated that their privacy and confidentiality was protected during their accessed to health services. This is consistent with the current practice in Malaysia where the HIV status of a patient can only be revealed with the explicit consent of a PLHIV.

This study had several limitations that should be taken into account in interpreting the results. Similar to studies in this area, these findings relied on self-reported responses and are subject to reporting and social desirability biases. Moreover, the study assessed only HCW employed in the government sector, with variable responses across governorates. As such, those working in the private sector may have different views and attitudes.

\section{Conclusion}

The findings of this study shared a worrying magnitude of stigma towards PLHIV among HCW in Malaysia. This stigma, however was not demonstrated in a form of discriminatory action in providing care and services towards PLHIV. Ethics and professionalism are upheld through giving good care and services to PLHIV. Nevertheless, stigma reduction intervention programmes are still needed to ensure continuous excellent service delivery in order to achieve "Three Zeros goals: Zero new HIV infection, Zero AIDS-related deaths and Zero HIV-related S\&D".

\section{Acknowledgements}

The authors thank the Director General of Health Malaysia for his permission to publish this paper. The authors also thank all the respondents who participated in the study.

\section{Authors' Contributions}

Analysis and interpretation of the data: ZHMY, MR

Drafting of the article: ZHMY

Critical revision of the article for important intellectual content: MR, AS

Final approval of the article: AS

\section{Competing Interests Statement}

The authors declare no conflicts of interest. The authors further declare that the study received no funding from any organizations or persons.

\section{References}

Boakye, D. S., \& Mavhandu-Mudzusi, A. H. (2019). Nurses knowledge, attitudes and practices towards patients with HIV and AIDS in Kumasi, Ghana. International Journal of Africa Nursing Sciences, 100147. https://doi.org/10.1016/j.ijans.2019.05.001

Chambers, L., Rueda, S., Baker, D., Wilson, M., Deutsch, R., Raeifar, E., \& Rourke, S. (2015) Stigma, HIV and 
health: A qualitative synthesis. BMC Public Health, 15, 848. https://doi.org/10.1186/s12889-015-2197-0

Houstan, P., Powell, E., Khan, J., Sultana, S., Kwagyan, J., Kharfen, M., \& Rana, S. (2019). Thirty-five years later: HIV stigma in Washington, DC health care workers. Journal of the Association of Nurses in AIDS Care, 30(3), 344-51. https://doi.org/10.1097/jnc.0000000000000060

International Health Policy Program, Thailand Ministry of Public Health. Report of a pilot: Developing tools and methods to measure HIV-related stigma and discrimination in health care settings in Thailand. Nonthaburi, Thailand: International Health Policy Program, 2014

Ledda, C., Cicciu, F., Puglisi, B., Ramaci, T., Nunnari, G., \& Rapisarda, V. (2017). Attitude of health care workers (HCWs) toward patient affected by HIV/AIDS and drug users: A cross-sectional study. International Journal of Environmental Research \& Public Health, 14(284), 1-8. https://doi.org/10.3390/ijerph14030284

Lui, P. S. C., Sarangapany, J., Begley, K., Coote, K., \& Kishore, K. (2014). Medical and nursing students perceived knowledge, attitudes and practices concerning human immunodeficiency virus. ISRN Public Health, 1-9. https://doi.org/10.1155/2014/975875

Malaysia Global AIDS Monitoring. (2020). Retrieved from https://www.moh.gov.my/moh/resources/Penerbitan/Laporan/Umum/Laporan_Global_AIDS_Monitoring_2 020_new.pdf

Maluwa, M., Aggleton, P., \& Parker, R. (2002) HIV-and AIDS-related stigma, discrimination and human rights: A critical overview. Health and Human Rights, 6(1), 1-18. https://doi.org/10.2307/4065311

Mukasa, D. S. (2006). Unveiling the truth, Shedding light on HIV stigma and discrimination. A report from the XVI International AIDS Conference, Toronto, Canada-August (pp.11-13).

Nyblade, L., Stangl, A., Weiss, E., \& Ashburn, K. (2009) Combating HIV stigma in health care settings: What works? Journal of the International AIDS Society, 12, 15. https://dx.doi.org/10.1186\%2F1758-2652-12-15

Nyblade, L., Jain, A., Benkirane, M., Li, L., Lohiniva, A. L., McLean, R., ... \& Thomas, W. (2013). A brief, standardized tool for measuring HIV-related stigma among health facility staff: results of field testing in China, Dominica, Egypt, Kenya, Puerto Rico and St. Christopher \& Nevis. Journal of the International AIDS Society, 16(2), 18718. https://dx.doi.org/10.7448\%2FIAS.16.3.18718

Ogden, J., \& Nyblade, L. (2005). Common at its core: HIV-related stigma across contexts. International Centre for Research on Women (ICRW), Washington, D.C., U.S.A.

Pitasi, M. A., Chavez, P. R., DiNenno, E. A., Jeffries, W. L., Johnson, C. H., Demeke, H., ... \& Bradley, H. (2018) Stigmatizing attitudes toward people living with HIV among adults and adolescents in the United States. AIDS and Behavior, 22(12), 3887-91. https://dx.doi.org/10.1007\%2Fs10461-018-2188-0

Policies and Procedures on Infection Prevention and Control. (2019). Retrieved from https://www.moh.gov.my/moh/press_releases/KKM\%20Policies\%20\&\%20Procedures\%20on\%20Infection \%20Prevention\%20and\%20Control\%202019.pdf

Srithanaviboonchai, K., Stockton, M., Pudpong, N., Chariyalertsak, S., Prakongsai, P., Chariyalertsak, C., ... \& Nyblade, L. (2017) Building the evidence base for stigma and discrimination-reduction programming in Thailand: development of tools to measure healthcare stigma and discrimination. BMC Public Health, 17, 245. https://doi.org/10.1186/s12889-017-4172-4

Tran, B. X., Phan, H. T., Latkin, C. A., Nguyen, H. L. T., Hoang, C. L., ... \& Ho, R.C.M. (2019) Understanding global HIV stigma and discrimination: Are contextual factors sufficiently studied? International Journal of Environmental Research and Public Health, 16(11), 1899. https://dx.doi.org/10.3390\%2Fijerph16111899

Vorasane, S., Jimba, M., Kikuchi, K., Yasuoka, J., Nanishi, K., Durham, J., \& Sychareun, V. (2017). An investigation of stigmatizing attitudes towards people living with HIV/AIDS by doctors and nurses in Vientiane, Lao PDR. BMC Health Services Research, 17, 125. https://dx.doi.org/10.1186\%2Fs12913-017-2068-8

WHO. (2007). Guidance on provider-initiated HIV testing and counselling in health facilities. Retrieved from http://www.who.int/hiv/pub/guidelines/9789241595568_en.pdf

Yasin, J., Fisseha, R., Mekonnen, F., \& Yirdaw, K. (2019) Occupational exposure to blood and body fluids and associated factors among health care workers at the University of Gondar Hospital, Northwest Ethiopia. Environmental Health and Preventive Medicine, 24, 18. https://doi.org/10.1186/s12199-019-0769-9 


\section{Copyrights}

Copyright for this article is retained by the author(s), with first publication rights granted to the journal.

This is an open-access article distributed under the terms and conditions of the Creative Commons Attribution license (http://creativecommons.org/licenses/by/4.0/). 